INTERDISCIPLINARIA ARCHAEOLOGICA

\title{
An Archaeometrical Analysis of the Column Bases from Hegmatâneh to Ascertain their Source of Provenance
}

\author{
Masoud Rashidi Nejad ${ }^{\mathrm{a}^{*}}$, Farang Khademi Nadooshan ${ }^{\mathrm{a}}$, Mostafa Khazaie ${ }^{\mathrm{a}}$, Paresto Masjedi ${ }^{\mathrm{a}}$ \\ ${ }^{a}$ Department of Archaeology at Tarbiat Modares University, 14115-139 Tehran, Iran
}

\section{ARTICLE INFO}

\section{Article history:}

Received: 15 April 2012

Accepted: 15 November 2012

\section{Key words:}

Achaemenid

Hamadan

Hegmatâneh

Petrography

XRD

\begin{abstract}
As a political and social statement, the style of the Achaemenid architecture was predicated on grandiose buildings and masonry, with the column as one of its primary elements. Often, the trunk of the columns was made of either wood or stone, although their bases were always made of stone; a practice unique to ancient Iran. Consequently, access to stone for building these columns was of major importance This paper deals with the sources used in the making of the column bases of Hegmatâneh following non-destructive techniques of petrography and XRD (X-ray Diffraction Spectrometry) analysis in conjunction with geological data. In order to study them, we collected six samples from Hamadan and nine from column bases. Historical texts and geological formations were also taken into consideration. This study attempts to demonstrate the relationship between archaeological and environmental data by statistical analysis, to be used as a tool for the identification of mineral resources in the future.
\end{abstract}

\section{Introduction}

Petrography and XRD are two methods for the recognition of stone sources. Relevant examples of using these methods include cylinder seals studies of the ancient Near East by using XRD (Collon 1989, 11-19), microscopic slices from the Achaemenid palace of Bardak-e-Siyah (Jafari 2005, 268), identification of the material composition of stones from Persepolis for repairing and preserving them (Amanolahi 2005, 68-75), and determining the cause of wear on the Bisotun engravings and preventing such deteriorations (Mohseni et al. 2007, 92-94). All of these studies have used at least one of the two methods.

According to Herodotus (The Histories, p. 54), at the time of Deioces (768 to $675 \mathrm{BC}$ ) Hegmatâneh was the capital of Media. In the Nabonidus chronicle, it is mentioned that Cyrus II, "The Great" (559-530 BC), seized Hamadan after defeating Astyages, king of the Medes ${ }^{1}$ (585 to 550

"Corresponding author. E-mail: mrashidinejad7@gmail.com

'URA-(gam- ta-in ordreis nu).
BC) (Grayson 1975, 106, 56). According to the Greek sources, Cyrus invaded Media because he wanted a political independence (Brosius 2006, 8).

From the point of view of stratification data, as a new architectural feature appeared. in Iran in Musiyan in the sixth millennium BC (Mirdavudi 1995, 37), Hasanlu IVB and C (1200-900 BC), columned halls from Mannaean period in the Solduz valley, south-west of Lake Urmia (Dyson 1965, 193-217; 1989, 107-127), wooden columns with stone bases at Godin II (800-400 BC) located approximately 12 kilometres south-east of the town of Kangavar (Yang 1967; 133-149), at Qalaichi (800-600 BC), near Bukan (Mollazadeh 2008, 107-125), and at Bābā Jān IA, II, Lūristan, with a large central hall and a double line of columns down the centre and a stone paved area at one end. The layout of Bābā Jān reveals possible connections with contemporaneous Assyrian palace architecture, as well as foreshadowing later Achaemenid constructions (Goff 1967, 133-149; 1970, 141-156).

Cyrus initiated the foundation of the first Persian royal centre, Pasargadae (Elamite: Batrakatash), on the plain of Marv Dasht in eastern Persia. The site was dominated by 

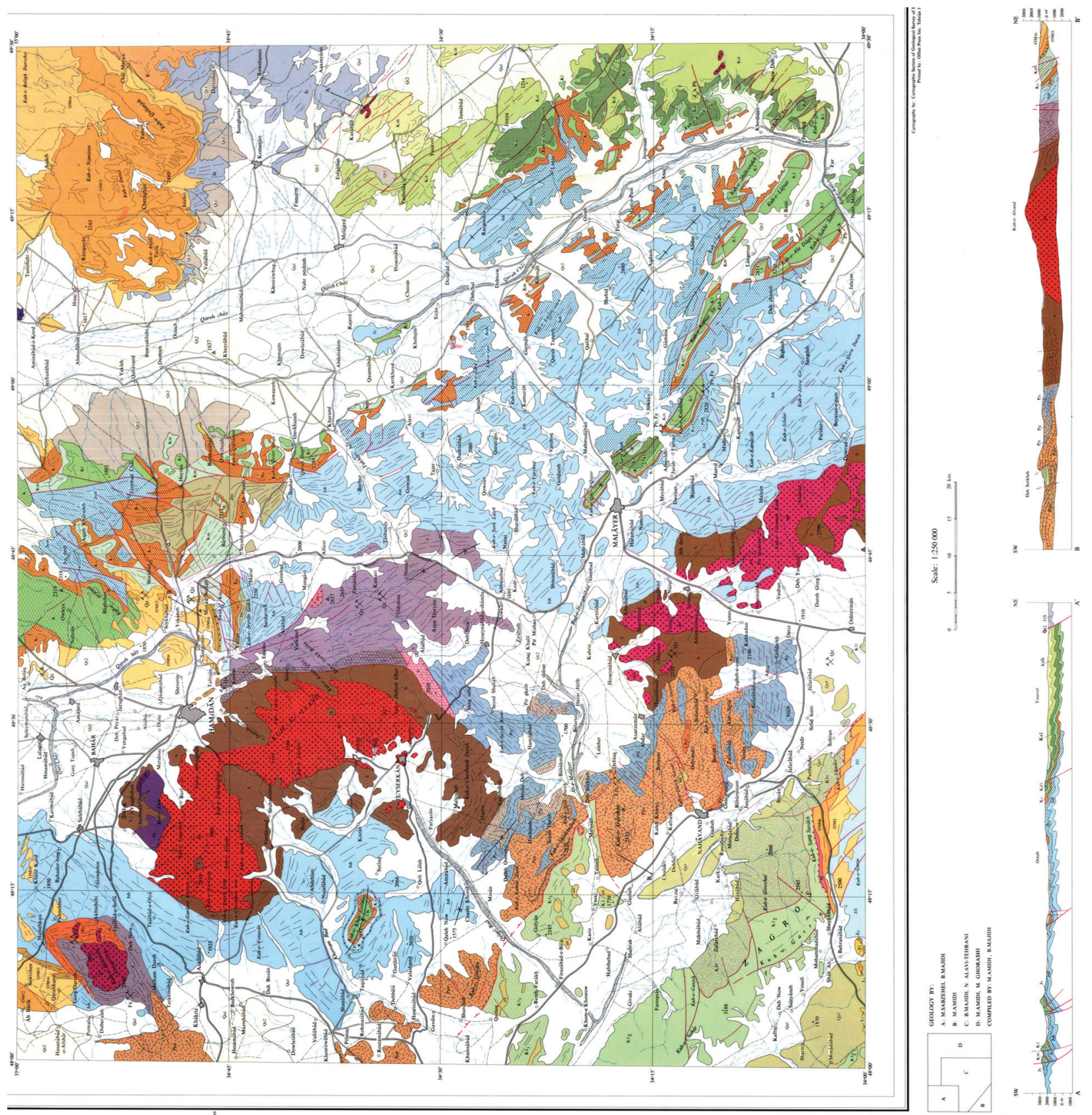

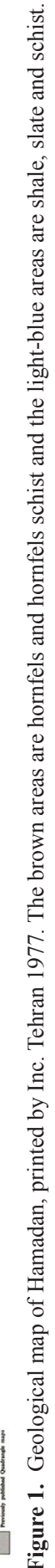

1/

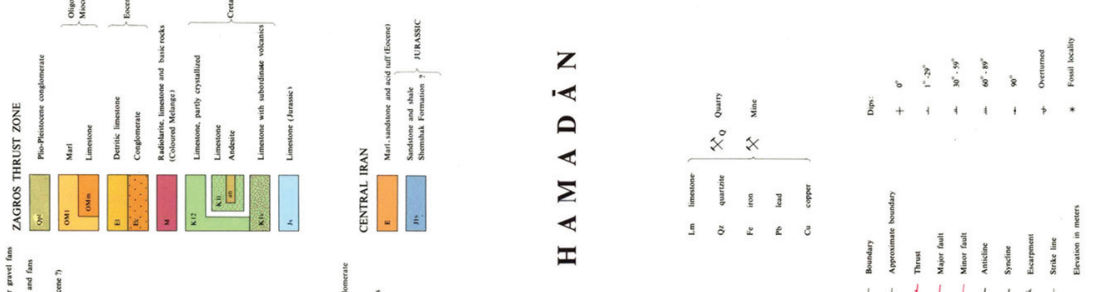

and

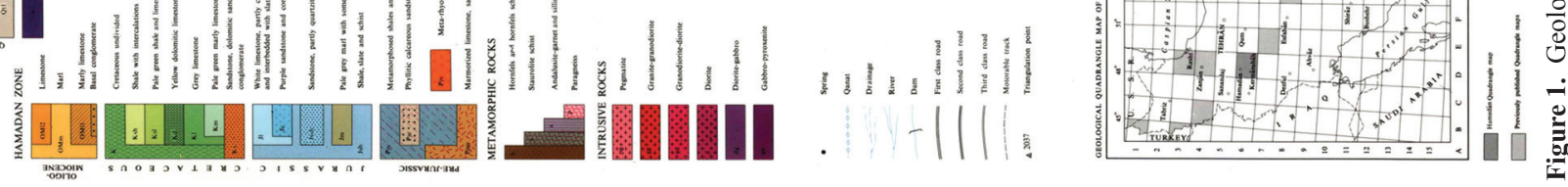



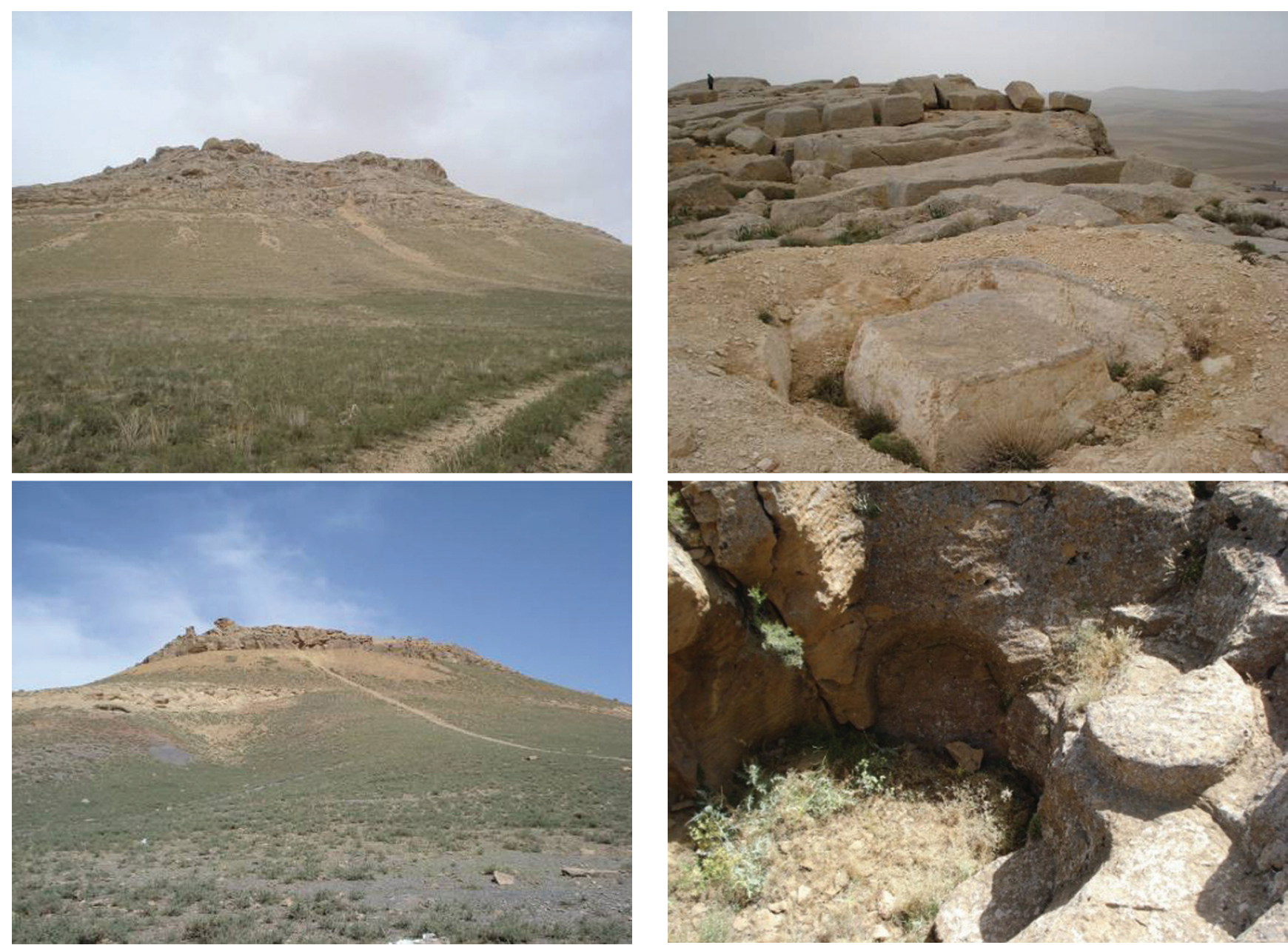

Figure 2. The methods of draw out from Khorzaneh, up, and Farhad Dash quarry, down. (Photos by authors)

Cyrus' palace and the audience hall, the residential palace, as well as his tomb, placed on a six-stepped platform (Brosius 2006, 9). The other royal Achamenid palaces were located in Apadana, Susa, Ecbatana and Persepolis reference. The column bases of Artaxerxes II in the Iran National Museum, four pieces of engraved columns in British and Japanese museums, and a column in the Hegmatâneh (Ecbatana) museum (Saraf et al. 2007, 51-66) are remains of this period. Since most of the columns discovered in hegmataneh and its surroundings are stratigraphically considered to belong to the Parthian Period (256 BC to 224 AD). consequently, scientific determination of the origin of the stone quarries was considered to be necessary.

\section{Geological overview}

Sanandaj-Sirjan zone is the metamorphic belt of the Zagros orogen in western Iran, which uplifted during the continental collision between the Afro-Arabian continent and the Iranian microcontinent (Mohajjel et al. 2006, 11-19). ALSbearing schists are part of the metamorphic rocks in the north-west half of the Sanandaj-Sirjan zone. They consist of metasediments including micaschist, garnet staurolite schist, garnet andalusite schist and garnet sillimanite schist (Figure 1) with protoliths of pelite interbedded in additional detritic sediments. Five episodes of deformation were recognized in the ALS-bearing schists (Ibid. 2006, 11-19).

\section{Methods and sampling}

\subsection{The XRD Method}

The XRD method is used in recognition of precious and semi-precious minerals and rocks, particularly with minerals such as hematite, quartz, rocks, limestone and metamorphic rocks, and inorganic compounds such as celadon and ceramic materials. The XRD method, along with XRF (X-ray fluorescence spectroscopy), is also used to detect the color of the minerals in the frescoes and stone statues and to determine the origin of the pottery and stone objects by tracing their constituent elements (Ellis, 2000, 671-672).

Three pieces of the column bases ( 3 X5 hala $\mathrm{cm}$ ya inch ya har vahede andazegiri ) and a sample of the stone base 


\section{IANSA 2012 • III/2 • $\quad 221-227$
Masoud Rashidi Nejad, Farang Khademi Nadooshan, Mostafa Khazaie, Paresto Masjedi: An Archaeometrical Analysis of the Column Bases from Hegmatâneh to
Ascertain their Source of Provenance}
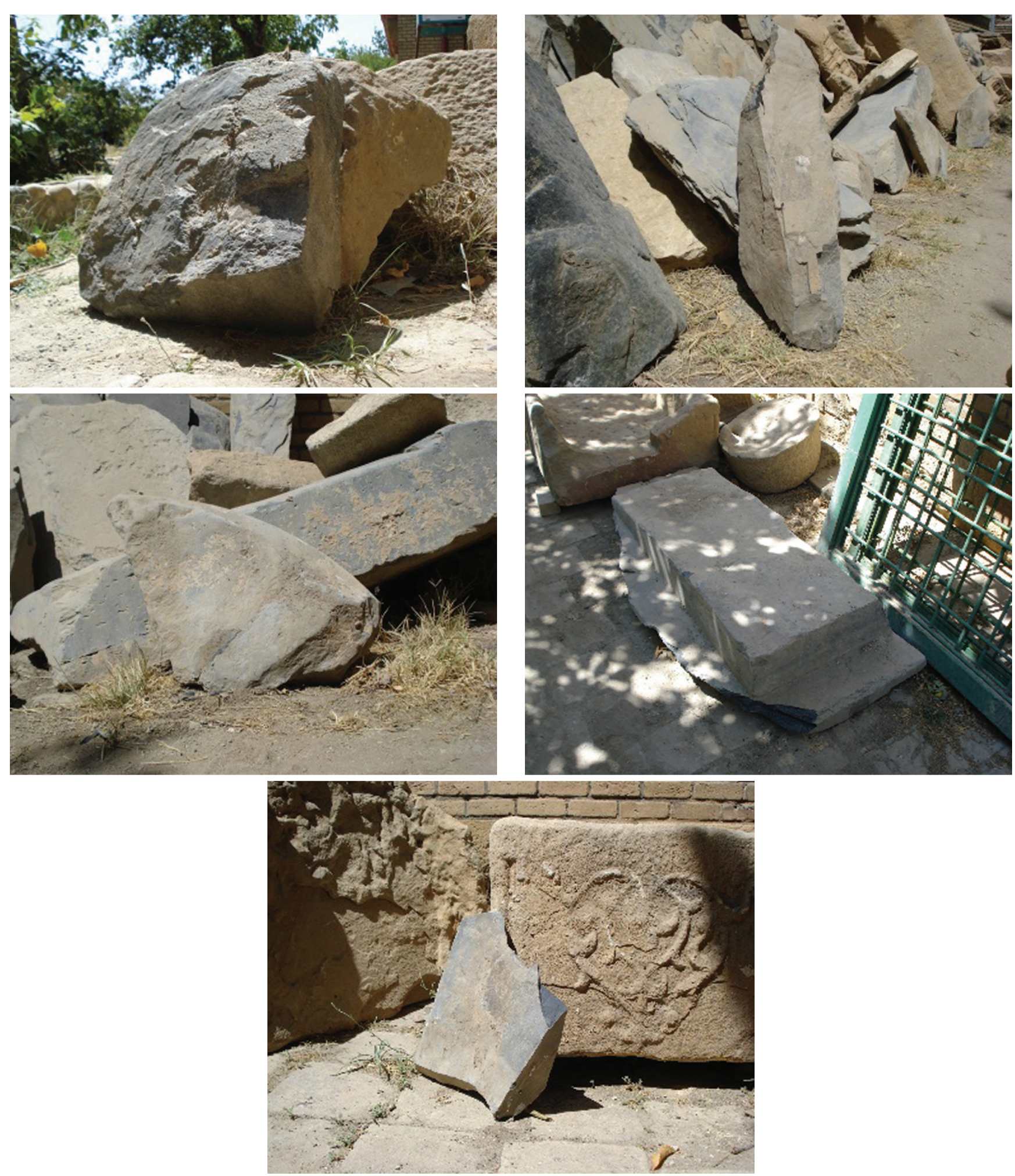

Figure 3. Samples number 5, 6 and 7, up,. 2 and 3, from the Achaemenid column bases used for analysis by XRD, (photos by authors). 
IANSA $2012 \bullet \quad$ III/2 • 22I-227
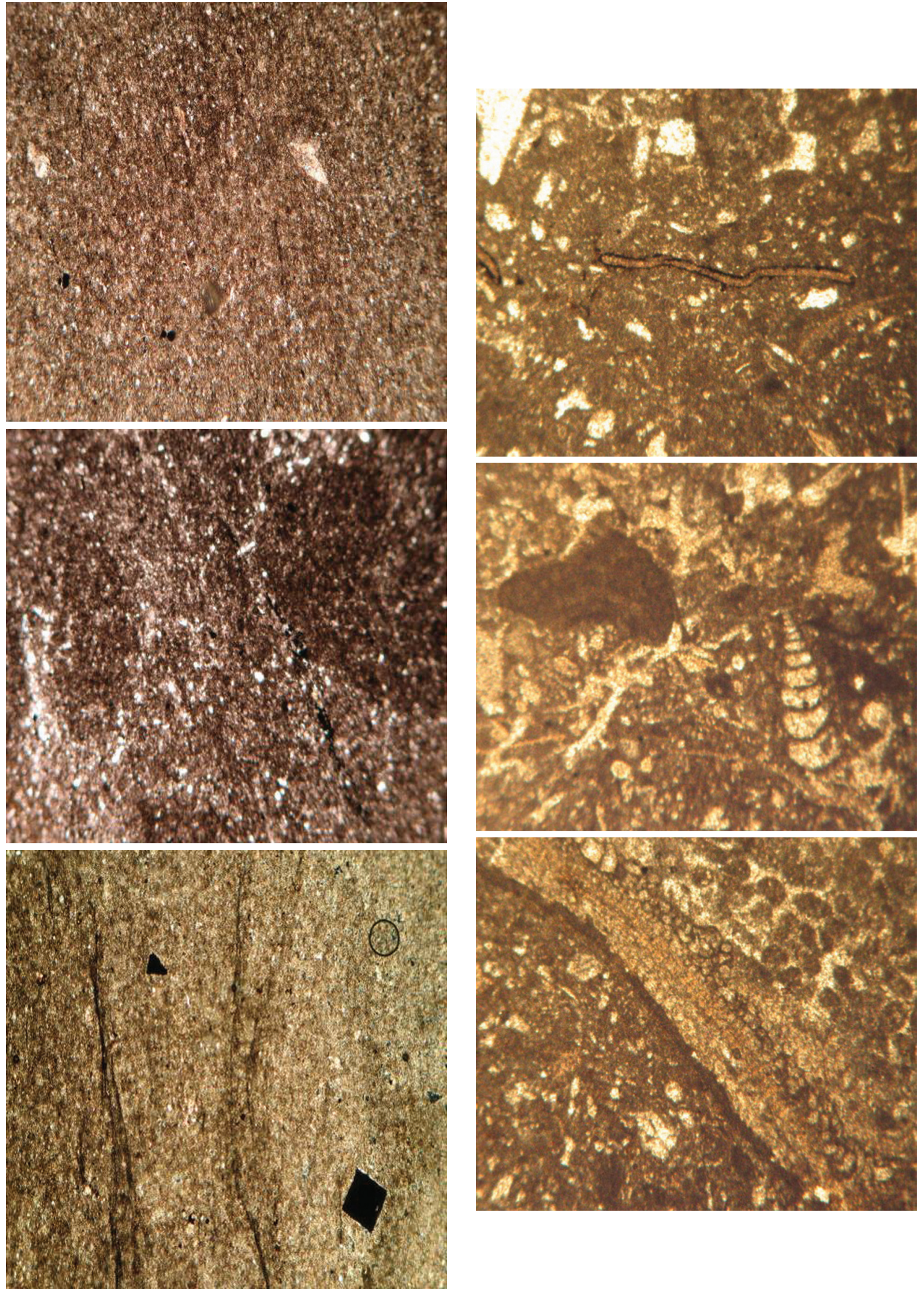

Up: a thin section image of pyrite crystal and solution veinlet, XPL, 40× magnification, H. 5.

Middle: images of a shale section, XPL, 40× magnification, H. 1.

Down: Images of a shale Mudstone section, XPL, $40 \times$ magnification, H. 2.

Middle: Pieces of foraminifera and echinoids, 20× magnification, PPL, F. 2.

Down: Traces of burrowing on a micrite background, $20 \times$ magnification, PPL, F. 1.

Figure 4. Texture of the samples of the column bases, above and the Farhad Dash quarry, below. 
Table 1. XRD analysis results: Samples 5, 6 and 7 are column bases from Hegmatâneh and Sample 8 is from the Hegmatâneh rocky outcropping. Samples 9, 10 and 11 are from Asadabad, Mosala and Emamzade-Kuh respectively. Samples 12 and 13 are from Divin and Abasabad. Key: Quartz: Qtz., Kaolinite: Kaol., Plagiocalse: Plag., Montmorillonite: Mo. Chlorite: Chlo., Calcite: Cc., Illite: Illi, Dolomite: Do., Andalusite: And. \& Mica: M.

\begin{tabular}{lll}
\hline Trace Phase & Minor Phases & Major Phases \\
\hline Kaol & Illi., Plag & Qtz., Cl \\
Chlo & Illi., Plag & Qtz., Cc \\
Chlo., Do & Illi, Plag & Qtz, Cc \\
- & Plag & Qtz., Illi \\
Kaol & Do & Qtz., Cc \\
Chlo, Do & Kaol & Qtz., Cc \\
Kaol & Plag & Qtz., Illi., M \\
And & Plag & Qtz., Illi., M \\
Kaol., And & Plag & Qtz., Illi., M \\
\hline
\end{tabular}

of Hegmataneh were analyzed at the XRD laboratory of the Geology Department of Bu-Ali Sina University² (Figure 3).

Sample No.1 is from a Hegmatâneh stone base containing quartz minerals ${ }^{3}$ calcite, potassic feldspar, illite and kaolinite compound. The sample is a low-grade metamorphosed mineral such as Chlorite, ilite and Kaolinite are low-grade metamorphic minerals. Quartz and calcite in the samples 2 and 3 are approximately the same ratio as the rocky outcrops of Hegmataneh. Even if the unstable base rocks of Hegnataneh make them inproper to be used in buildings. The differences between these samples are due to the mineral ratios of their main components not their variety, the type of rock and the natural macheanisms resulting from the metamorphosis of the Alvand Mountains.

The range of the Alvand Mountains depicts a higher metamorphosis ratio and a higher percentage of unstable minerals ( clay and calcite ) like what is found in the samples taken from Divin and Abbasabad (Numbers 8 and 9).

Sample 4 consists of a higher quantity of quartz also it might be sandstone as well. These homogeneous stones spread from the North ot the West of Hamedan, next to Shavarin, the village of Baghche and Sabzabad, some 20 $\mathrm{km}$ from Hamadan (Table 1). From a mineralogical point of view, the samples from Asadabad, Mosala and EmamzadeKuh (Numbers 5, 6 and 7) are similar to those from the pedestal samples.

\footnotetext{
${ }^{2}$ The sample preparation procedures greatly vary. There are five basic types of procedures: grinding, dissolution, melting and embedding. Powdering (or grinding) of samples is a simple preparation method required in a number of spectrometric and spectroscopic techniques, such as XRD. (DoménechCarbó \& Costa 2009: 10).

${ }^{3}$ The presence of quartz is important because rocks and minerals composed chiefly of quartz make up a large percentage of the lithic artifacts. Quartz is the most stable of all the minerals under sedimentary conditions and in the Earth's surface environment (Ellis 2000, 530).
}

\subsection{Petrographic analysis ${ }^{4}$}

In order to distinguish the quarry sources, mineralogical and palaeontological methods are utilised (Henderson 2000, 27). The geological and petrographic studies of the column bases from Hegmatâneh indicate that the shale stone used (mixed with pyrite at times) comes from one or more quarries with similar geological characteristics. After considering the petrology of lime samples from Farhad Dash and Khorzaneh mines, we cut three thin sections from Farhad Dash named F.1-3 and nine from the column bases (H.1-9). In order to distinguish the calcite from the dolomite, we colored them by red alizarin solvent per the Dixon method (1965). A coloration and petrography study by polarizing microscope indicated that the mineralogical character of the samples is a compound of calcite. The additional minerals encompass a small amount of terrigenous quartz and second hematite (Figure 4).

\section{Discussion}

Khorzaneh is one of the ancient quarries mentioned in the historical texts. Yaghot Homavi reports that Alexander the Great ordered the construction of the famous stone lion of Hamadan ("Shir Sangi") after his return from Babylon in 334 BC by quarrying stone from this quarry (Azkaii 2001, 1-200). Our research cannot confirm this assertion. Engravings and additional archaeological finds among which is pottery (from the second half of the first millennium $\mathrm{BC}$ ).

The other quarry, Farhad Dash, is in Salehabad, $45 \mathrm{~km}$ from Hamadan. This quarry is similar to the open quarry found in the Sivand Mountains of Fars province (Rezai 2006, 78), Hussein-Kuh near Naqsh-e-Rostam (Huff 2004, 395-396) and Qadamgah south-west of Rahmat-Kuh, which belong to the Achaemenid period (Bessac 2007, 187-206). From this quarry, blocks of limestone $4.70 \mathrm{~m} \times 1-3 \mathrm{~m}$ were divided into pieces of $1.10 \times 1.10$ or $83 \times 58 \mathrm{~cm}$, and these were later transported from the highlands to valley (Figure 2).

Considering that kind of Achaemenid column bases are different from the Khorzaneh and Farhad Dash stones, the petrographic data and XRD analysis revealed that the Achaemenids used low-grade metamorphic stones from rocky outcrops in Hamadan and its environs. However it is to be noted, they primarily used non-flaky stones with resistance and beauty such as sedimentary rock of slate or shale which form NW-SE trending heights around Hamadan: Asadabad, Mosala or Emamzade-Kuh. Other sources used by the Achaemenids to construct buildings include sandstone ${ }^{5}$

${ }^{4}$ Most lithic composed of minerals The minerals are crystalline, thus the petrography is based on crystal symmetry and crystal chemistry. Thinsection petrography requires the use of a polarizing microscope. The polarizing microscope has two functions: (1) to provide an enlarged image of an object placed on the microscope stage, and (2) to provide plane and crossed polarized light and convergent light (Rapp 2009, 24).

${ }^{5}$ Presumably sandstone not used by Achaemenian, because it is not conform to form and quantity of column bases. 
and hornfels from North-East, west and south Hamadan (the result of the Alvand stone transformation, see Figure 2, nr. 5.

\section{Conclusion}

The analytical studies of the quarry activity during the Achaemenid period (although not associated with what mentioned of analytical aspect), and their mineralogical variety in the specific stones utilized for the construction, based on geological context of Hamadan are signs of native resources.

\section{Acknowledgements}

We would like to thank Rashid Baeygi the former head of the Hegmatâneh project as well as Hassan Mohseni and Behroz Rafii for their assistance with XRD and the petrographic analysis at Bu-Ali Sina University and Haj Valii and Rashid Abdorezaii a post-graduate student of geology at the National University of Iran.

\section{References}

AMANOLAHI, H. 2005: Studying Variety of Stones Used in Platform of Takhte Jamshid, Persian Journal of Iranian Studies, 1/2, 68-75.

AZKAII, P. 2001: Hamadan-Nameh, Hamadan, Nashre Madestan, 1-200. BESSAC, J-C. 2007: Étude Technique et Interoetations du Monument Rupestre de Monument Rupester de Qadamgah (Fars), Iranica Antiqua XLII, 185-206.

BROSIUS, M. 2006: The Persians: An Introduction. Routledge, LondonNew York

COLLON, D. 1989: Materials and Techniques of Ancient Near Eastern Cylinder Seals, In: Hackens, T., Moucharte, G. (Eds): Technology and Analysis of Ancient Gemstones. PACT 23, Council of Europe, Strasbourg, 11-19.

DOMÉNECH-CARBÓ A., DOMÉNECH-CARBÓ M. T, COSTA V. 2009: Electrochemical Methods in Archaeometry, Conservation and Restoration. Springer.

DYSON, R. H. 1989: The Iron Age Architecture at Hasanlu: an Essay, Expedition, 31/2-3, 107-127.
DYSON, R. H. 1965: Problems of Prehistoric Iran as Seen from Hasanlu, Journal of Near Eastern Studies, 24/3, 193-217.

ELLIS, L. 2000: Archaeological Method and Theory: An Encyclopedia. Garland Publishing, New York - London.

GOFF, C. L. 1967: Survey of an Excavation in Iran during 1965-66, Journal of Persian Studies V, 133-149.

GOFF, C. L. 1970: Excavations at Bābā Jān, 1968: Third Preliminary Report, Journal of Persian Studies VIII, 141-156.

GHORBANI, M., PARVIN-PUR. F. 2001: Tarikh Madan va Madan-kari dar Iran (The History of Mines and Mining in Iran), Maghalate Iran-shenasi, Tehran, Bonyade Iran-shenasi, 271-297.

GRAYSON, A. K. 1975: Assyrian and Babylonian Chronicles. Locust Valley, New York.

HENDERSON, J. 2000: The Science and Archaeology of Materials, Routledge, London - New York.

HERODOTUS: The Histories, translated Aubrey De Sélincourt (Penguin Books, 1954).

RAPP, G. 2009: Archaeo Mineralogy, Herrmann, B, Wagner, A. (Eds.), Springer.publisher, Günther.

HILARY, G. 2005: The Shape of Sherds: Function and Style at Godin II, Iranica Antiqua XL, 249-269.

HUFF, D. 2004: Pre-Islamic Quarry and Stone-Technology in Iran. Persiens Antike Pracht. Katalog der Ausstellung des Deutschen Bergbau, Museums Bochum.

JAFARI, M. A. 2005: Baresi Microscopy va Macroscopic Sotonhaye Achaemenian va Madane Poze Palangie Rahdar, Gozareshaye Bastanshenasi 4, Pajoheshcadye Bastan Shenasi, 256-275.

MEHRYAR, M.: Baresi Avamel Memari Mohavate Hegmataneh, Asar, Nashriye Meli Hefazate Asar Bastani, 3/7, 8, 9, 88-95.

MOHAJJEL, M, BAHARIFAR, A, MOINEVAZIRI. H., NOZAEM. R, 2006: Deformation History, Micro-structure and P-T-t paths in ALSbearing Schists, Southeast Hamadan, Sanandaj-Sirjan Zone, Iran, Journal of Geological Society of Iran, 1, 11-19.

MOHSENI, H., KHODABAKHSH, S., SADR, H., ALIYANI. F. 2007: Motale Sang-negari va Systeme Darzh Dantaghe Bisotun Baraye Paybordan be Elale Farsayash Sang-neveshte Bisoton, Majale Olome Zamin, $16 / 63,92-94$

MOLLAZADEH, K. 2008: The Pottery from the Mannean Site of Qalaichi, Bukan (NW-Iran), Iranica Antiqua, XLIII, 107-125.

NEPTON, P. SARAF, M.- R., CERTIS, J. 2007: Paye Sotonhaye Katiedare Hamadan, Bastan Shenasi va Tarikh, 39-40, 51-66.

REZAII, A. A. 2006: Takhte Jamshid Payetakhte Tamadon va Farhange Iran va Jahan, Eghbal Publishing, Tehran.

SAX, M. 1991: The composition of the Materials of First Millennium B.C. Cylinder Seals From Western Asia, In: Budd, P., Chapman, B., Jackson, C., Janaway, R., Ottaway, B. (Eds): Archaeological Sciences 1989, Oxbow Monograph 9, Oxbow, Oxford, 104-114.

T. CUYLER YOUNG. 1967: Survey of excavation in Iran during 1965-66, Journal of Persian Studies V, 133-149. 
